\title{
Sudden Infant Death Syndrome: Case-Control Frequency Differences at Genes Pertinent to Early Autonomic Nervous System Embryologic Development
}

\author{
DEBRA E. WEESE-MAYER, ELIZABETH M. BERRY-KRAVIS, LILI ZHOU, BRION S. MAHER, \\ MARK E. CURRAN, JEAN M. SILVESTRI, AND MARY L. MARAZITA \\ Departments of Pediatrics [D.E.W.-M., E.M.B.-K., L.Z., J.M.S.] and Neurology [E.M.B.-K.] and \\ Biochemistry, Rush Children's Hospital at Rush University Medical Center, Chicago, IL 60612, U.S.A.; \\ Center for Craniofacial and Dental Genetics [B.S.M., M.L.M.], Division of Oral Biology, School of Dental \\ Medicine, University of Pittsburgh, Pittsburgh, PA 15219, U.S.A.; DNA Sciences, Inc. [M.E.C.], Fremont, \\ CA, 94555, U.S.A.; and Department of Human Genetics [M.L.M.], Graduate School of Public Health, and \\ Department of Oral and Maxillofacial Surgery, School of Dental Medicine, University of Pittsburgh, \\ Pittsburgh, PA 15219, U.S.A.
}

\begin{abstract}
We have previously identified polymorphisms in the serotonin transporter gene promoter region and in intron 2 that were more common among sudden infant death syndrome (SIDS) cases compared with control subjects. To elucidate further the genetic profile that might increase an infant's vulnerability to SIDS, we focused on the recognized relationship between autonomic nervous system (ANS) dysregulation and SIDS. We therefore studied genes pertinent to early embryologic development of the ANS, including MASH1, BMP2, PHOX2a, PHOX2b, RET, $E C E 1, E D N 1, T L X 3$, and EN1 in 92 probands with SIDS and 92 gender- and ethnicity-matched control subjects. Eleven proteinchanging rare mutations were identified in 14 of 92 SIDS cases among the PHOX2a, RET, ECE1, TLX3, and EN1 genes. Only 1 of these mutations (TLX3) was identified in 2 of 92 control subjects. Black infants accounted for 10 of these mutations in SIDS cases and 2 control subjects. Four protein-changing common polymorphisms were identified in $B M P 2, R E T, E C E 1$, and $E D N 1$, but the allele frequency did not differ between SIDS cases and control subjects. However, among SIDS cases, the allele frequency for the $B M P 2$ common polymorphism demonstrated
\end{abstract}

\section{ABSTRACT}

ethnic differences; among control subjects, the allele frequency for the $B M P 2$ and the ECE1 common polymorphisms also demonstrated ethnic differences. These data represent further refinement of the genetic profile that might place an infant at risk for SIDS. (Pediatr Res 56: 391-395, 2004)

$\quad$ Abbreviations
SIDS, sudden infant death syndrome
5HTT, serotonin transporter gene
ANS, autonomic nervous system
CCHS, congenital central hypoventilation syndrome
BMP2, bone morphogenic protein-2 gene
MASH1, mammalian achaete-scute homolog-1 gene
PHOX, paired-like homeobox gene
RET, rearranged during transfection factor
ECE1, endothelin converting enzyme-1 gene
EDN1, endothelin-1 gene
TLX3, T-cell leukemia homeobox gene
EN1, engrailed-1 gene

Sudden infant death syndrome (SIDS) is the sudden and unexpected death of an infant under $1 \mathrm{y}$ of age that remains

Received January 15, 2004; accepted March 31, 2004.

Correspondence: Debra E. Weese-Mayer, M.D., Department of Pediatrics at Rush University Medical Center, Pediatric Respiratory Medicine at Rush Children's Hospital, 1653 West Congress Parkway, Chicago, IL 60612, U.S.A. E-mail: Debra_E_Weese-Mayer@rsh.net

Supported by The CJ Foundation for SIDS, the Joseph Tyler Gertler SIDS Research Fund, The Justin Carl Suth SIDS Research Fund, and the Spastic Paralysis and Allied Diseases of the Central Nervous System Research Foundation of the Illinois-Eastern Iowa District Kiwanis International.

DOI: 10.1203/01.PDR.0000136285.91048.4A unexplained after a thorough clinical history, death scene investigation, and postmortem examination (1). Introduction of an aggressive Back to Sleep campaign in 1992 targeting identified modifiable environmental risk factors for SIDS led to a decrease in SIDS incidence from 1.2 per 1000 live births (2) to 0.55 per 1000 live births in 2001 (3). Despite this decline, black infants maintain a higher SIDS incidence and a slower decline rate when compared with white infants $(2,3)$. Furthermore, infants of all ethnic groups continue to succumb to SIDS despite full compliance with known modifiable risk factors. These observations have led investigators to consider the pos- 
sibility of gene-by-environment interaction (whereby an environmental condition or toxin affects gene expression) as an explanation for the remaining 2234 infants who died from SIDS in 2001 in the United States alone (3).

The serotonin transporter gene (5HTT) was the first gene linked to SIDS vulnerability. This gene was studied on the basis of reports of decreased serotonergic receptor binding in brainstems of SIDS victims in the United States (4) and Japan (5). Narita et al. (6) demonstrated an association between a promoter polymorphism in $5 H T T$, known to differentially regulate transporter expression, and SIDS risk by describing an excess of the more effective promoter long (L) allele in the Japanese SIDS group relative to control subjects. We confirmed this association in white and black SIDS cases relative to control subjects (7) and then reported an association between SIDS and a $5 H T T$ intron 2 polymorphism, also known to regulate $5 H T T$ expression (8). The association was significant in black SIDS cases versus control subjects, with the SIDSassociated genotype leading to more effective transporter production (12 allele). Furthermore the promoter and intron 2 loci were in linkage disequilibrium, and the L-12 haplotype was significantly associated with SIDS in the black subgroups. These results provide strong evidence for a relationship between SIDS risk and 5HTT gene activity and represent a first step in the study of a genetic basis for SIDS.

Because serotonin influences a broad range of physiologic systems, including the regulation of breathing, the cardiovascular system, temperature, and the sleep-wake cycle (9), serotonin is likely involved in regulation of the autonomic nervous system (ANS). Observations consistent with ANS dysfunction have been reported in SIDS, including profuse sweating (10), elevated body temperature $(11,12)$, tachycardia then bradycardia preceding the terminal event (13), reduced heart rate variability (14-16), drenching sweats and facial pallor (17), and decreased responses to obstructive sleep events (18). Accordingly, to elucidate further the genetic profile that might increase an infant's vulnerability to SIDS, we focused on genes pertinent to the embryologic origin of the ANS. This approach has been successful in clarifying the genetic basis of idiopathic congenital central hypoventilation syndrome (CCHS), known to have associated ANS dysregulation (19-21) and thought to be related to SIDS (22). Children with CCHS have been recently identified as heterozygous for the paired-like homeobox protein $(P H O X) 2 \mathrm{~b}$ polyalanine expansion mutation in $40-97 \%$ of cases (23-25). Just as in the early investigation of CCHS, we hypothesized that a subset of SIDS cases might have unique mutations or polymorphisms in genes identified embryologically or through knock-out models to be involved in ANS regulation.

Therefore, in the current study, we examined bone morphogenic protein-2(BMP2) $(24,26,27)$, mammalian achaete-scute homolog-1 (MASH1) (28-30), PHOX2a (31-35), rearranged during transfection factor $(R E T)(36-42)$, endothelin converting enzyme-1 $(E C E 1)(24,43)$, endothelin-1 (EDN1) (44), T cell leukemia homeobox protein $(T L X 3)(24,45-47)$, and engrailed-1 $(E N 1)(48,49)$ genes by sequence analysis in a cohort of infants who succumbed to SIDS. We also screened the SIDS cohort for the CCHS-associated polyalanine repeat mutation in $P H O X 2 b$. It was anticipated that infants who succumbed to SIDS might have unique mutations in the studied genes that would further clarify the genetic profile of the at-risk infant and explain the ethnic disparity in incidence.

\section{METHODS}

Study population. Two distinct groups were investigated in this study: 92 SIDS cases and 92 matched control subjects. Ethnicity was assigned on the basis of self-report or report of the mother. This study was approved by the Rush University Medical Center institutional review board.

SIDS cases. A total of 92 SIDS cases (mean age at death: $95 \mathrm{~d} \pm 52$; 3 of $92<28 \mathrm{~d} ; 9$ of $92>180 \mathrm{~d}$; median age: $85 \mathrm{~d}$, 25th and 75th percentiles: 56 and $110 \mathrm{~d}$, respectively) with a diagnosis made by the University of Maryland Medical Examiner were identified in the University of Maryland Brain and Tissue Bank (21 black girls, 25 black boys, 16 white girls, and 30 white boys). The diagnosis of SIDS was based on the accepted definition: the sudden and unexpected death of an infant under $1 \mathrm{y}$ of age that remains unexplained after a thorough clinical history, death scene investigation, and postmortem examination (1).

Control subjects. A total of 92 unrelated control subjects were matched for ethnicity and gender to the SIDS cases with a 1:1 match ratio. After informed consent was obtained, a three-generation family history was taken for each control subject to ensure that no family member had a diagnosis of SIDS, Hirschsprung disease, CCHS, apparent life-threatening event, primary (nonacquired) disorder of ANS dysregulation, or tumor of neural crest origin.

DNA preparation. Fixed frozen frontal cortex brain tissue from SIDS subjects was obtained from the University of Maryland Brain and Tissue Bank for Developmental Disorders (http://medschool.umaryland.edu/btbank/main.html). Blood from control subjects $(3-10 \mathrm{~mL})$ was obtained by venipuncture and collected in an EDTA tube. Genomic DNA was isolated from the brain and blood samples using standard methods as described previously (7).

PCR amplification and direct DNA sequencing of purified PCR products for BMP2, MASH1, PHOX2a, RET, ECE1, $E D N 1, T L X 3$, and EN1. Oligonucleotide primer pairs that spanned each exon to be sequenced [sequences for genes published previously (24); sequences for primers for RET gene available upon request] and divided each region into segments of $\sim 500$ nucleotides in length were designed using the automatic primer selection algorithm Primer 3.0. When Primer 3.0 was unable to identify suitable primer pairs, primary DNA sequence data were reviewed by the investigators and primers were selected manually. Standard PCR amplification was carried out as described (24). All sequence assemblies and polymorphisms were manually reviewed to ensure accuracy of variant identification.

Genotyping of PHOX2b polyalanine repeat sequence. The PHOX $2 b$ exon 3 region coding for the polyalanine repeat was amplified with primer pair 5'-CCAGGTCCCAATCCCAAC-3' (forward) and 5'-GAGCCCAGCCTTGTCCAG-3' (reverse) as described previously (24) (patent pending). 
Strategy for mutation analysis. DNA from all 92 SIDS cases and from 26 control subjects was sequenced for exon and splice site mutations in BMP2, MASH1, PHOX2a, RET, ECE1, $E D N 1, T L X 3$, and $E N 1$. Any base change expected to affect a splice site or result in modification of the protein sequence that was identified in SIDS subjects but not control subjects was further screened in all 92 control subjects. Any potential protein-changing polymorphisms that occurred in SIDS or control subjects were screened in all 92 control subjects to determine whether any of these polymorphisms was associated with SIDS. Samples from the SIDS and control groups were screened for the $\mathrm{PHOX} 2 \mathrm{~b}$ polyalanine repeat expansion associated with CCHS.

Statistical analysis. For each case-control comparison, we computed standard $\chi^{2}$ tests of independence between allele frequency and SIDS phenotype. Under the null hypothesis of no allele frequency differences, the test statistic follows a $\chi^{2}$ distribution with degrees of freedom equal to one less than the number of alleles. When data were sparse (expected counts fewer than five in any cell), we used Fisher's exact test to examine hypotheses regarding allelic association. Analyses were conducted within the matched sample data set, including 92 ethnicity- and gender-matched SIDS cases and control subjects.

\section{RESULTS}

Genotype analyses in SIDS cases and control subjects. Data in Table 1 indicate protein-changing variants in 92 SIDS cases and 92 control subjects for the candidate genes. No protein-changing alterations were identified for $M A S H 1$ or EDN1. Sequence data from PHOX2a, RET, ECE1, TLX3, and EN1 revealed 11 rare protein-changing polymorphisms in 14 SIDS cases (15.2\% of SIDS cases), and subsequent genotyping for these polymorphisms in control subjects identified 1 polymorphism in 2 control subjects (2.2\% of control subjects). Each of these mutations occurred in a single SIDS case with the exception of the $T L X 3$ base change, which occurred in four
SIDS cases and two control subjects. Black infants accounted for 10 of the SIDS cases and the 2 control subjects with protein-changing mutations.

Four common protein-changing polymorphisms were identified in $B M P 2, R E T, E C E 1$, and $E D N 1$. The allele frequency did not differ between SIDS cases and control subjects, but the RET polymorphism approached significance for the SIDS versus control comparison $(p=0.072)$. Among SIDS cases, the allele frequencies for the $B M P 2$ common polymorphism were significantly different between white and black infants $(p<$ 0.0001 ). Among control subjects, the allele frequencies for the $B M P 2$ and ECE1 polymorphisms were significantly different between white and black infants $(p<0.0001$ and $p=0.025$, respectively). None of the other comparisons reached significance.

Directed mutation analysis of polyalanine repeat sequence in PHOX2b. None of the SIDS subjects demonstrated the PHOX $2 b$ mutation seen in CCHS. All SIDS subjects had the normal genotype with 20 polyalanine-coding repeats on each chromosome. Among control subjects, one black and two white infants were heterozygous for deletion variants that contained 14 and 15 repeats, respectively, as previously reported in control populations $(23,24)$.

\section{DISCUSSION}

These results represent the first report describing analysis of homeobox and signal transduction genes important in specifying cell fate in ANS differentiation in SIDS cases. Our finding of specific protein-changing mutations in PHOX2a, RET, ECE1, TLX3, and EN1 among $15.2 \%$ of SIDS cases versus $2.2 \%$ of control subjects suggests that specific polymorphisms in these genes may confer some SIDS risk. The observation that $71 \%$ of the SIDS cases with these mutations were black may be consistent with the observed ethnic disparity in SIDS, although black populations tend to exhibit higher levels of genetic variation. The identification of ethnic disparity among SIDS cases and among control subjects for the protein-

Table 1. Protein-changing variants for 92 SIDS and 92 control subjects

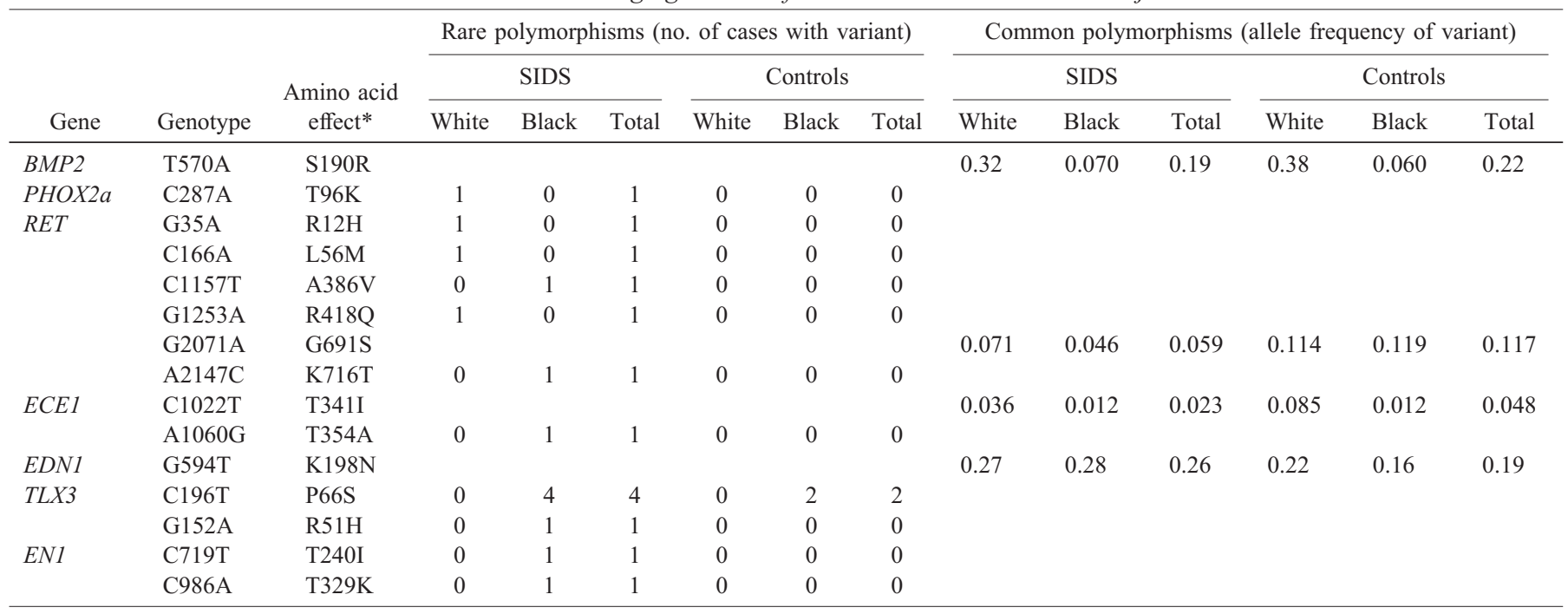

* Change in the amino acid sequence in the protein resulting from the mutation (e.g. A386V means that the alanine at amino acid position 386 in the protein was changed to a valine). 
changing common polymorphisms identified in $B M P 2$ and $E C E 1$ is consistent with population-dependent variation commonly observed at polymorphic sites. The higher incidence for these common polymorphisms among whites may confer protection or may have potential relevance to yet unidentified genes or in a larger data set. Our observation that none of the SIDS cases demonstrated the $P H O X 2 b$ polyalanine expansion mutation previously identified in CCHS indicates less specific overlap between the two diseases than previously considered (children with CCHS have generalized ANS dysregulation and typically present in the newborn period and require artificial ventilatory support; infants who succumb to SIDS are seemingly normal yet have ANS dysregulation). However, as families of CCHS probands have a higher incidence of SIDS history in a family member (22) and as the anticipated incidence of this $P H O X 2 b$ mutation is low in the general population, our sample size may not have been adequate to detect a case. Therefore, it may still be appropriate to evaluate infants with SIDS for the CCHS PHOX2b mutation to ascertain that CCHS was not the cause of death.

The mutations identified in this study may be benign polymorphisms or may be mutations specifically related to the SIDS phenotype. Insufficient information is currently available to distinguish these possibilities; however, all of the rare mutations in Table 1 were conserved in the mouse and the rat, with the exception of the RET R12H, RET A386V, EN1 T240I, and ECE1 T354A (although this was conserved in the frog and the cow). Mutations that occur in conserved amino acid residues (as determined through GenBank at www.ncbi.nlm.nih.gov/Genbank) are more likely to disrupt normal protein function and thus more likely to be related to the SIDS phenotype. Any amino acid change, even in nonconserved residues, however, may be responsible for some level of risk. The low rate of occurrence of mutations in this study suggests that there are yet unidentified genes that are responsible for the SIDS phenotype. It should also be noted that none of these rare mutations, with the exception of the TLX3 P66S, has been reported in GenBank, the National Institutes of Health genetic sequence database with an annotated collection of all publicly available currently known DNA sequences.

The greatest number of rare mutations was identified in the $R E T$ gene. This is of particular interest because of the relationship of RET to Hirschsprung disease and to CCHS and because of the RET knock-out model with a depressed ventilatory response to inhaled carbon dioxide with decreased frequency and tidal volume (42). The knock-out models for ECE1 (43) and $T L X 3$ (45) also include impaired breathing and/or early death in the mouse phenotype, with suggestion of a central respiratory deficit. On the basis of these interesting and suggestive findings, further research is necessary to understand better the role of these and other genes in the SIDS phenotype and in explaining the ethnic disparity in SIDS.

Acknowledgments. We thank Foster Lewin for the preparation of the DNA; Chinton Desai and Ronak Lahkia, who assisted with PCR assays; Amy Drendel, M.D., and Mary Hayes, M.S.N., for recruitment efforts; and the SIDS cases and their parents, as well as the control subjects who graciously shared their DNA.

\section{REFERENCES}

1. Willinger M, James LS, Catz C 1991 Defining the sudden infant death syndrome (SIDS): deliberations of an expert panel convened by the National Institute of Child Health and Human Development. Pediatr Pathol 11:677-684

2. Kochanek KD, Hudson BL 1995 Advance report of final mortality statistics, 1992. Mon Vital Stat Rep 43(65):10-12.

3. Arias E, MacDorman MF, Strobino DM, Guyer B 2003 Annual summary of vital statistics-2002. Pediatrics 112:1215-1230

4. Panigrahy A, Filiano J, Sleeper LA, Mandell F, Valdes-Dapena M, Krous HF, Rava LA, Foley E, White WF, Kinney HC 2000 Decreased serotoninergic receptor binding in rhombic lip-derived regions of the medulla oblongata in the sudden infant death syndrome. J Neuropathol Exp Neurol 59:377-384

5. Ozawa Y, Okado N 2002 Alteration of serotonergic receptors in the brain stems of human patients with respiratory disorders. Neuropediatrics 33:142-149

6. Narita N, Narita M, Takashima S, Nakayama M, Nagai T, Okado N 2001 Serotonin transporter gene variation is a risk factor for sudden infant death syndrome in the Japanese population. Pediatrics 107:690-692

7. Weese-Mayer DE, Berry-Kravis EM, Maher BS, Silvestri JM, Curran ME, Marazita ML 2003 Sudden infant death syndrome: association with a promoter polymorphism of the serotonin transporter gene. Am J Med Genet 117A:268-274

8. Weese-Mayer DE, Zhou L, Berry-Kravis EM, Maher BS, Silvestri JM, Marazita ML 2003 Association of the serotonin transporter gene with sudden infant death syndrome: a haplotype analysis. Am J Med Genet 122A:238-245

9. Jacobs BL, Azmitia EC 1992 Structure and function of the brain serotonin system. Physiol Rev 72:165-229

10. Kahn A, Groswasser J, Rebuffat E, Sottiaux M, Blum D, Foerster M, Franco P, Bochner A, Alexander M, Bachy A, Richard P, Verghote M, Le Polain D, Wayenberg JL 1992 Sleep and cardiorespiratory characteristics of infant victims of sudden death: a prospective case-control study. Sleep 15:287-292

11. Fleming PJ, Gilbert R, Azaz Y, Berry PJ, Rudd PT, Stewart A, Hall E 1990 Interaction between bedding and sleeping position in the sudden infant death syndrome: a population based case-control study. BMJ 301:85-89

12. Ponsonby AL, Dwyer T, Gibbons LE, Cochrane JA, Jones ME, McCall MJ 1992 Thermal environment and sudden infant death syndrome: case-control study. BMJ 304:277-282

13. Meny RG, Carroll JL, Carbone MT, Kelly DH 1994 Cardiorespiratory recordings from infants dying suddenly and unexpectedly at home. Pediatrics 93:44-49

14. Schechtman VL, Harper RM, Kluge KA, Wilson AJ, Hoffman HJ, Southall DP 1988 Cardiac and respiratory patterns in normal infants and victims of the sudden infant death syndrome. Sleep 11:413-424

15. Ledwidge M, Fox G, Matthews T 1998 Neurocardiogenic syncope: a model for SIDS. Arch Dis Child 78:481-483

16. Franco P, Szliwowski H, Dramaix M, Kahn A 1998 Polysomnographic study of the autonomic nervous system in potential victims of sudden infant death syndrome. Clin Auton Res 8:243-249

17. Taylor BJ, Williams SM, Mitchell EA, Ford RP 1996 Symptoms, sweating and reactivity of infants who die of SIDS compared with community controls. The New Zealand National Cot Death Study Group. J Paediatr Child Health 32:316-322

18. Franco P, Szliwowski H, Dramaix M, Kahn A 1999 Decreased autonomic responses to obstructive sleep events in future victims of sudden infant death syndrome. Pediatr Res 46:33-39

19. Weese-Mayer DE, Shannon DC, Keens TG, Silvestri JM 1999 American Thoracic Society Statement: idiopathic congenital central hypoventilation syndrome. Diagnosis and management. Am J Respir Crit Care Med 160:368-373

20. Weese-Mayer DE, Silvestri JM, Huffman AD, Smok-Pearsall SM, Kowal MH, Maher BS, Cooper ME, Marazita ML 2001 Case/control family study of autonomic nervous system dysfunction in idiopathic congenital central hypoventilation syndrome. Am J Med Genet 100:237-245

21. Marazita ML, Maher BS, Cooper ME, Silvestri JM, Huffman AD, Smok-Pearsall SM, Kowal MH, Weese-Mayer DE 2001 Genetic segregation analysis of autonomic nervous system dysfunction in families of probands with idiopathic congenital central hypoventilation syndrome. Am J Med Genet 100:229-236

22. Weese-Mayer DE, Silvestri JM, Marazita ML, Hoo JJ 1993 Congenital central hypoventilation syndrome: inheritance and relation to sudden infant death syndrome. Am J Med Genet 47:360-367

23. Amiel J, Laudier B, Attié-Bitach T, Trang H, de Pontual L, Gener B, Trochet D, Etchevers H, Ray P, Simonneau M, Vekemans M, Munnich A, Gaultier C, Lyonnet S 2003 Polyalanine expansion and frameshift mutations of the paired-like homeobox gene PHOX2B in congenital central hypoventilation syndrome. Nat Genet 33:459-461

24. Weese-Mayer DE, Berry-Kravis EM, Zhou L, Maher BS, Silvestri JM, Curran ME, Marazita ML 2003 Idiopathic congenital central hypoventilation syndrome: analysis of genes pertinent to early autonomic nervous system embryologic development and identification of mutations in PHOX2b. Am J Med Genet 123A:267-278

25. Sasaki A, Kanai M, Kijima K, Akaba K, Hashimoto M, Hasegawa H, Otaki S, Koizumi T, Kusuda S, Ogawa Y, Tuchiya K, Yamamoto W, Nakamura T, Hayasaka K 2003 Molecular analysis of congenital central hypoventilation syndrome. Hum Genet 114:22-26

26. Lo L, Sommer L, Anderson DJ 1997 MASH1 maintains competence for BMP2-induced neuronal differentiation in post-migratory neural crest cells. Curr Biol 7:440-450

27. Lo L, Guillemot F, Joyner AL, Anderson DJ 1994 MASH-1: a marker and a mutation for mammalian neural crest development. Perspect Dev Neurobiol 2:191-201 
28. Guillemot F, Lo LC, Johnson JE, Auerbach A, Anderson DJ, Joyner AL 1993 Mammalian achaete-scute Homolog 1 is required for the early development of olfactory and autonomic neurons. Cell 75:463-476

29. Dauger S, Renolleau S, Vardon G, Népote V, Mas C, Simonneau M, Gaultier C, Gallego J 1999 Ventilatory responses to hypercapnia and hypoxia in Mash-1 heterozygous newborn and adult mice. Pediatr Res 46:535-542

30. Johnson JE, Birren SJ, Anderson DJ 1990 Two rat homologues of Drosophila achaete-scute specifically expressed in neuronal precursors. Nature 346:358-361

31. Hirsch MR, Tiveron MC, Guillemot F, Brunet JF, Goridis C 1998 Control of noradrenergic differentiation and Phox $2 a$ expression by MASHI in the central and peripheral nervous system. Development 125:599-608

32. Lo L, Morin X, Brunet JF, Anderson DJ 1999 Specification of neurotransmitter identity by Phox2 proteins in neural crest stem cells. Neuron 22:693-705

33. Lo L, Tiveron M, Anderson DJ MASH1 activates expression of the paired homeodomain transcription factor Phox $2 a$, and couples pan-neuronal and subtype-specific components of autonomic neuronal identity. Development 125:609-620, 1998

34. Pattyn A, Morin X, Cremer H, Goridis C, Brunet JF 1997 Expression and interactions of the closely related homeobox genes Phox $2 a$ and Phox $2 b$ during neurogenesis. Development 124:4065-4075

35. Pattyn A, Morin X, Cremer H, Goridis C, Brunet JF 1999 The homeobox gene Phox $2 b$ is essential for the development of autonomic neural crest derivatives. Nature 399:366-370

36. Bolk S, Angrist M, Schwartz S, Silvestri JM, Weese-Mayer DE, Chakravarti A 1996 Congenital central hypoventilation syndrome: mutation analysis of the receptor tyrosine kinase. RET. Am J Med Genet 63:603-609

37. Amiel J, Salomon R, Attié T, Pelet A, Trang H, Mokhtari M, Gaultier C, Munnich A, Lyonnet S 1998 Mutations of the RET-GDNF signaling pathway in Ondine's curse. Am J Hum Genet 62:715-717

38. Sakai T, Wakizaka A, Matsuda H, Nirasawa Y, Itoh Y 1998 Point mutation in exon 12 of the receptor tyrosine kinase proto-oncogene RET in Ondine-Hirschsprung syndrome. Pediatrics 101:924-926

39. Sakai T, Wakizaka A, Nirasawa Y 2001 Congenital central hypoventilation syndrome associated with Hirschsprung's disease: mutation analysis of the RET and endothelinsignaling pathways. Eur J Pediatr Surg 11:335-337
40. Kanai M, Numakura C, Sasaki A, Shirahata E, Akaba K, Hashimoto M, Hasegawa H, Shirasawa S, Hayasaka K 2002 Congenital central hypoventilation syndrome: a novel mutation of the RET gene in an isolated case. Tohoku J Exp Med 196:241-246

41. Fitze G, Paditz E, Schlafke M, Kuhlisch E, Roesner D, Schackert HK 2003 Association of germline mutations and polymorphisms of the RET proto-oncogene with idiopathic congenital central hypoventilation syndrome in 33 patients. J Med Genet 40:E10

42. Burton MD, Kawashima A, Brayer JA, Kazemi H, Shannon DC, Schuchardt A, Costantini F, Pachnis V, Kinane TB 1997 RET proto-oncogene is important for the development of respiratory $\mathrm{CO}_{2}$ sensitivity. J Auton Nerv Syst 63:137-143

43. Renolleau S, Dauger S, Vardon G, Levacher B, Simonneau M, Yanagisawa M, Gaultier C, Gallego J 2001 Impaired ventilatory responses to hypoxia in mice deficient in endothelin-converting-enzyme-1. Pediatr Res 49:705-712

44. Kuwaki T, Cao W, Kurihara Y, Kurihara H, Ling GY, Onodera M, Ju KH, Yazaki Y, Kumada M 1996 Impaired ventilatory responses to hypoxia and hypercapnia in mutant mice deficient in endothelin-1. Am J Physiol 270:R1279-R1286

45. Shirasawa S, Arata A, Onimaru $\mathrm{H}$, Roth KA, Brown GA, Horning S, Arata S, Okumura K, Sasazuki T, Korsmeyer SJ 2000 Rnx deficiency results in congenital central hypoventilation. Nat Genet 24:287-290

46. Amiel J, Pelet A, Trang H, de Pontual L, Simonneau M, Munnich A, Gaultier C, Lyonnet $\mathrm{S} 2003$ Exclusion of $R N X$ as a major gene in congenital central hypoventilation syndrome (CCHS, Ondine's curse). Am J Med Genet 117A:8-20

47. Matera I, Bachetti T, Cinti R, Lerone M, Gagliardi L, Morandi F, Motta M, Mosca F, Ottonello G, Piumelli R, Schober JG, Ravazzolo R, Ceccherini I 2002 Mutational analysis of the $R N X$ gene in congenital central hypoventilation syndrome. Am J Med Genet 113:178-182

48. Simon HH, Saueressig H, Wurst W, Goulding MD, O'Leary DD 1994 Fate of midbrain dopaminergic neurons controlled by the engrailed genes. J Neurosci 21:3126-3134

49. Zec N, Rowitch DH, Bitgood MJ, Kinney HC 1997 Expression of the homeoboxcontaining genes EN1 and EN2 in human fetal midgestational medulla and cerebellum. J Neuropathol Exp Neurol 56:236-242 